Crop Breeding and Applied Biotechnology 12: 220-223, 2012

Brazilian Society of Plant Breeding. Printed in Brazil

CULTIVAR RELEASE

\title{
BRS Notável: a medium-early-maturing, disease-resistant Carioca common bean cultivar with high yield potential
}

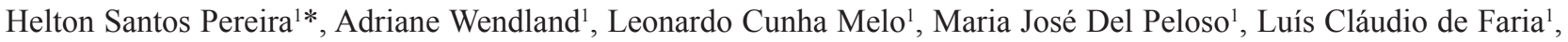
Joaquim Geraldo Cáprio da Costa ${ }^{1}$, Adriano Stephan Nascente ${ }^{1}$, José Luis Cabrera Díaz ${ }^{1}$, Hélio Wilson Lemos de Carvalho², Válter Martins de Almeida ${ }^{3}$, Carlos Lásaro Pereira de $\mathrm{Melo}^{4}$, Antônio Félix da Costa ${ }^{5}$, Sheila Cristina Prucoli Posse ${ }^{6}$, Juarez Fernandez de Souza ${ }^{7}$, Ângela de Fátima Barbosa Abreu ${ }^{1}$, Mariana Cruzick de Sousa Magaldi ${ }^{1}$, Cléber Moraes Guimarães $^{1}$ and Jaison Pereira de Oliveira ${ }^{1}$

Received 23 September 2011

Accepted 02 June 2012

\begin{abstract}
BRS Notável is a common bean cultivar with carioca grain, suitable for cultivation in 20 Brazilian states. It is a mediumearly-maturing cultivar, with an average yield of 2,261 $\mathrm{kg} \mathrm{ha}^{-1}, 8.5 \%$ higher than the controls, a high yield potential $(4,472 \mathrm{~kg} \mathrm{ha-1})$, lodging tolerance and resistance to anthracnose, fusarium wilt, common bacterial blight, and curtobacterium wilt.
\end{abstract}

Key words: Early maturity, bacterial blight, fusarium wilt.

\section{INTRODUCTION}

Brazil is the world's largest producer of common beans, which are the primary protein source in the Brazilian diet. The consumers have regional preferences in terms of grain color and type, aside from cooking quality characteristics. The states of the South, Southeast and Midwest of the country produce most of the carioca grain, which accounts for about $70 \%$ of the total consumption (Del Peloso and Melo 2005). To meet this demand, the bean is sown year-round, in various cropping systems. In 2009, 2.9 million tons of common beans were produced on an area of 2.5 million hectares, i.e., a national average yield of $1,160 \mathrm{~kg} \mathrm{ha}^{-1}$ (http:// www.cnpaf.embrapa.br/apps/socioeconomia/index.htm).

Currently, producers desire new cultivars that are highyielding, earlier, more disease-resistant and upright, and which can be mechanically harvested, ensuring a better quality product and higher crop profits for the farmers. The demand for earlier cultivars is on the rise because these crops can be more flexibly scheduled, saving irrigation wa- ter, energy, etc. To date, few cultivars of the Carioca group have this earliness trait, e.g., Carioca Precoce, BRS 9435 Cometa (Faria et al. 2008) and BRSMG Talismã (Abreu et al. 2004). Another important characteristic of new common bean cultivars is the resistance to diseases such as fusarium wilt, anthracnose, angular leaf spot, white mold, common bacterial blight, and bean golden mosaic virus, which cause substantial production losses.

\section{BREEDING METHODS}

BRS Notável was obtained from crosses between the lines A 769 /4/ A 774 /// A 429 / XAN 252 // V 8025 / G 4449 /// WAF 2 / A55 // GN 31 / XAN 170 carried out in 1990, at the International Center for Tropical Agriculture (CIAT). Embrapa Rice and Beans received the population in the $\mathrm{F}_{4}$ generation from the CIAT, and the subsequent selection stages were performed in Santo Antônio de Goiás. In 1995, the $\mathrm{F}_{4}$ population was sown and blight-resistant plants were selected, representing the population in the following generation. Selection was also

\footnotetext{
${ }^{1}$ Embrapa Arroz e Feijão, Rod. GO 462, km 12, CP 179, 75.375-000, Santo Antônio de Goiás, GO, Brazil. *E-mail: helton@cnpaf.embrapa.br

${ }^{2}$ Embrapa Tabuleiros Costeiros, Avenida beira Mar, 3250, Bairro Jardins, CP 44, 49.025-040, Aracaju, SE, Brazil

${ }^{3}$ Empresa de Pesquisa Agropecuária e Extensão Rural de Mato Grosso, Rua Jari Gomes, 454, CP 225, 78.068-690, Cuiabá, MT, Brazil

${ }^{4}$ Embrapa Agropecuária Oeste, Rod. BR 163, km 253, 6, CP 449, 79.804-790, Dourados, MS, Brazil

5 Instituto Agronômico de Pernambuco, Avenida General San Martin, 1371, Bairro Bongi, 50.761-000, Recife, PE, Brazil

${ }^{6}$ Instituto Capixaba de Pesquisa, Assistência Técnica e Extensão Rural, Rua Afonso Sarlo, 160, Bairro Bento Ferreira, 29.052-010, Vitória, ES, Brazil

7 Fundação Estadual de Pesquisa Agropecuária do Rio Grande do Sul, Rua Gonçalves Dias, 570, Bairro Menino Deus, 90.130-060, Porto Alegre, RS, Brazil
} 
performed for standards of the carioca grain. In the $\mathrm{F}_{5}$ generation, plants were selected for resistance to anthracnose, angular leaf spot and rust, resulting in $\mathrm{F}_{5: 6}$ families, in 1996. In 1997, $\mathrm{F}_{5: 6}$ families were selected for resistance to rust and angular leaf spot. In 1998, in the $\mathrm{F}_{5: 7}$ generation, selection among families and selection of plants within the best families was performed for bacterial blight resistance, plant architecture, grain yield and carioca grain characteristics. In 2000, lines in the $\mathrm{F}_{7: 8}$ generation were selected for yield and plant architecture, among which line LM 200203909 was selected.

Thereafter, this line was evaluated in replicated tests for grain yield and other relevant traits, e.g., disease reaction, plant architecture, etc. (Melo 2009). In 2001, the line was assessed in the Preliminary Carioca Test in a randomized block design with

Table 1. Grain yield of BRS Notável compared with the average of two controls in tests of Value for Cultivation and Use, for state and season, from 2005 to 2010

\begin{tabular}{|c|c|c|c|c|c|}
\hline State & Season & $\begin{array}{c}\text { BRS } \\
\text { Notável } \\
\left(\mathrm{kg} \mathrm{ha}^{-1}\right)\end{array}$ & $\begin{array}{c}\text { Control } \\
\text { mean } \\
\left(\mathrm{kg} \mathrm{ha}^{-1}\right)\end{array}$ & $\begin{array}{c}\text { Relative } \\
\text { yield (\%) }\end{array}$ & $\begin{array}{l}\text { Number of } \\
\text { environments }\end{array}$ \\
\hline \multirow[t]{4}{*}{ GO/DF } & Rainy & 1806 & 1564 & 117.5 & 10 \\
\hline & Dry & 1272 & 1297 & 101.7 & 8 \\
\hline & Winter & 2863 & 2713 & 107.6 & 9 \\
\hline & General & 2000 & 1868 & 109.5 & 27 \\
\hline MT & Winter & 3076 & 2866 & 106.9 & 3 \\
\hline TO & Winter & 1967 & 2039 & 96.5 & 1 \\
\hline ES & Rainy & 1386 & 1559 & 88.9 & 1 \\
\hline RJ & Winter & 2142 & 1910 & 110.9 & 2 \\
\hline BA & Rainy & 2315 & 2291 & 102.3 & 8 \\
\hline \multirow[t]{4}{*}{ SP } & Rainy & 2609 & 2426 & 106.5 & 13 \\
\hline & Dry & 2296 & 1989 & 117.3 & 8 \\
\hline & Winter & 3241 & 2927 & 110.8 & 8 \\
\hline & General & 2697 & 2443 & 110.7 & 29 \\
\hline MS & Dry & 2159 & 1984 & 110.1 & 7 \\
\hline \multirow[t]{3}{*}{ PR } & Rainy & 2156 & 2118 & 103.2 & 23 \\
\hline & Dry & 2193 & 1899 & 120.7 & 16 \\
\hline & General & 2171 & 2028 & 110.3 & 39 \\
\hline \multirow[t]{3}{*}{$\mathrm{SC}$} & Rainy & 2718 & 2594 & 103.2 & 16 \\
\hline & Dry & 2000 & 1918 & 108.1 & 13 \\
\hline & General & 2396 & 2291 & 105.4 & 29 \\
\hline \multirow[t]{3}{*}{ RS } & Rainy & 2001 & 2115 & 89.5 & 7 \\
\hline & Dry & 1322 & 1303 & 103.8 & 6 \\
\hline & General & 1688 & 1740 & 96.1 & 13 \\
\hline SE & Rainy & 2627 & 2322 & 115.3 & 9 \\
\hline $\mathrm{AL}$ & Rainy & 1247 & 975 & 128.0 & 3 \\
\hline PE & Rainy & 2393 & 2083 & 116.8 & 4 \\
\hline General & & 2262 & 2113 & 108.5 & 175 \\
\hline
\end{tabular}

three replications, in two 4-m rows, along with over 109 lines and four controls, at four locations: Santo Antônio de Goiás (GO), Seropédica (RJ), Ponta Grossa (PR), and Lavras (MG).

In 2003, LM 200203909 was assessed in the Intermediate Test along with another 24 lines and five controls, in a randomized block design with three replications, in four 4-m rows, in seven environments: Santo Antônio de Goiás (GO) - rainy season (sowing in November); Ponta Grossa (PR) - rainy (sowing in October) and dry season (sowing in January); Lavras (MG) - winter (sowing in July); Sete Lagoas (MG) - dry season (sowing in March); Simão Dias (SE) rainy season (sowing in May); and Seropédica (RJ) - winter (sowing in June). The combined data analyses for grain yield and other agronomic traits indicated line LM 200203909, now with the pre-commercial name CNFC 10408, for the tests of Value for Cultivation and Use (VCU).

In 2004, sufficient seed was produced for sowing in the VCU tests. From 2005 to 2010, line CNFC 10408 was evaluated in 175 tests with several controls (Pérola, Iapar 81, BRS Pontal, BRS 9435 Cometa, BRS Estilo, IAC Alvorada, IAC Carioca, IPR Tangará, SCS Guará, and BRS Requinte), in a randomized block design with four replications of four 4-m rows, using the recommended technologies for each environment and cropping system.

\section{GRAIN YIELD AND YIELD POTENTIAL}

In the 175 VCU tests conducted from 2005 to 2010 , the average grain yield of BRS Notável (CNFC 10408) was 8.5\% higher than that of the control (Pérola, Iapar 81, BRS Pontal, BRS 9435 Cometa, BRS Estilo, IAC Alvorada, IAC Carioca, IPR Tangará, SCS Guará, and BRS Requinte), in the following seasons and states: winter (May/June) - Tocantins, Mato Grosso and Rio de Janeiro; rainy season (April/May) - Sergipe, Alagoas, Pernambuco, Bahia and Espirito Santo (October/ November); dry season (February/March) - Mato Grosso do Sul,; rainy (September/October) and dry season (January/February) - Santa Catarina, Parana and Rio Grande do Sul; and rainy season (September/October/November), dry season(February/ March) and winter (May/June) - Goiás, Distrito Federal and São Paulo (Table 1). The yield performance of BRS Notável was $6 \%$ higher than that of cultivar Pérola, which is the standard cultivar of the Carioca group, widely planted in the country.

The average yield of BRS Notável was 2,261 $\mathrm{kg} \mathrm{ha}^{-1}$, compared with $2,116 \mathrm{~kg} \mathrm{ha}^{-1}$ of the controls and $2,138 \mathrm{~kg} \mathrm{ha}^{-1}$ of cultivar Perola. In all tests, two controls were included for comparison, one of which was cultivar Pérola in all tests. Preferably, the second control was cultivar Iapar 81 . Otherwise, one of the other varieties mentioned above was used, according to the constitution of the tests. 
BRS Notável: a medium-early-maturing, disease-resistant Carioca common bean cultivar with high yield potential

The data of the planting seasons and states showed that in Alagoas, in the rainy season, the average performance of BRS Notável was $28 \%$ better than that of the controls. In Paraná, which accounts for approximately $27 \%$ of the country's common bean production, and is consequently, the largest bean-producing state in Brazil (http://www.cnpaf.embrapa.br/ apps/socioeconomia/index.htm), BRS Notável had an average yield of 2,156 kg ha' ${ }^{-1}$ and 2,193 kg.ha-1 in the rainy and dry seasons, respectively, exceeding the controls by $3 \%$ and $21 \%$, respectively. In São Paulo and Goiás/Federal District, which are the third and fourth largest producing states, respectively, the performance of BRS Notável also exceeded the controls by $11 \%$ and $10 \%$, respectively, in the average of all seasons.

The average yield potential of BRS Notável in the five tests in which the cultivar achieved the highest yields, was $4,472 \mathrm{~kg} \mathrm{ha}^{-1}$. This shows that the cultivar has a high genetic potential and that high yields can be achieved if the environment is favorable and growing conditions are good.

Based on its performance, BRS Notável can be recommended for planting in Goiás, Distrito Federal, Mato Grosso, Tocantins, Maranhão, Bahia, Espírito Santo, Rio de Janeiro, Mato Grosso do Sul, Paraná, Santa Catarina, São Paulo, Rio Grande do Sul, Sergipe, Alagoas, Pernambuco, Rio Grande do Norte, Piauí, Ceará, and Paraíba.

\section{OTHER TRAITS}

In terms of grain quality traits that are relevant for food processing and industry, BRS Notável has regular grain color and size and an average 100 -grain weight of 26 grams, similar to the controls Iapar 81 and Pérola (Table 2) and less than IAC Alvorada (28 grams) (Carbonell et al. 2008). The mean cooking time of BRS Notável is $31 \mathrm{~min}$, slightly higher than that of the controls (on average $28 \mathrm{~min}$ ). Regarding the protein percentage, the average content of BRS Notável was also slightly higher, around $23 \%$, compared to $21 \%$ of the controls.

Under artificial inoculation, BRS Notável was resistant to bean common mosaic virus and to the pathotypes 65,73 , 81,89 and 453 of Colletotrichum lindemuthianum, the causal agent of anthracnose. It also proved moderately resistant to
Table 2. Traits of common bean cultivar BRS Notável, compared to the controls Pérola and IAPAR 81

\begin{tabular}{llll}
\hline Cultivar & $\begin{array}{l}\text { Cooking time } \\
\text { (min) }\end{array}$ & $\begin{array}{l}\text { Protein content } \\
(\mathbf{\%})\end{array}$ & $\begin{array}{l}\text { 100-grain } \\
\text { weight }(\mathbf{g})\end{array}$ \\
\hline BRS Notável & 31 & 23 & 26 \\
\hline IAPAR 81 & 29 & 19 & 25 \\
\hline Pérola & 27 & 22 & 27 \\
\hline
\end{tabular}

curtobacterium wilt. In field tests, it was moderately resistant to anthracnose, fusarium wilt, common bacterial blight and rust. However, it was susceptible to angular leaf spot and bean golden mosaic virus (Table 3 ).

The BRS Notável has a medium-early-maturing cycle (75-84 days from emergence to physiological maturity), similar to BRS 9435 Cometa (Faria et al. 2008). This cycle is about 10 days shorter than of the cultivars with this grain type that are currently in use. Earlier cultivars allow farmers to schedule harvest schemes with greater flexibility and to save water, energy, etc. The plants are bushy, with indeterminate growth habit type II. The plant architecture of BRS Notável is semi-erect with good lodging resistance, even suitable for direct mechanical harvesting. The flowers are white and pods at physiological maturity yellow. At harvest maturity, the pods are regularly sandy-yellow. The grains are carioca (beige with brown stripes), with a nearly full elliptical shape, not shiny, similar to the cultivars Pérola and BRS Estilo (Melo et al. 2010).

The particular features of BRS Notável are the early maturity combined with high yield potential, resistance to bean common mosaic virus and moderate resistance to anthracnose, bacterial blight and fusarium wilt. The advantages of this new over the other Carioca grain cultivars indicated above are a higher average yield and yield potential and enhanced resistance to fusarium wilt, bacterial blight and curtobacterium wilt than of BRS 9435 Cometa (Faria et al . 2008), which is also medium-early maturing (in 75-84 days). Compared to normal-maturing cultivars, BRS Notável has a greater yield and better grain standard than BRS Requinte (Faria et al. 2004) and also greater resistance to common bacterial blight and fusarium wilt than BRS Estilo (Melo et al. 2010).

Table 3. Agronomic traits and disease reaction of BRS Notável, compared to the carioca controls Pérola and BRS 9435 Cometa

\begin{tabular}{lcclcccccccc}
\hline Cultivar & Cycle & W100 & ARCH & AN & CBC & RU & ALS & BCMV & BGMV & FW & CW \\
\hline BRS Notável & SE & 26 & Semi-upright & MR & MR & MR & S & R & S & MR & MR \\
\hline Pérola & N & 27 & Semi-upright & S & S & MS & MS & R & S & MS & S \\
\hline BRS 9435 Cometa & SE & 25 & Upright & MR & S & MR & S & R & S & S & S \\
\hline
\end{tabular}

W100- 100-grain weight (grams), ARCH - Plant architecture; AN-Anthracnose; CBB- Common bacterial blight; RU-Rust; ALS- angular leaf spot; BCMV - bean common mosaic virus; BGMV- Bean golden mosaic virus; FW-Fusarium wilt; CW - curtobacterium wilt, N-normal cycle; SE- Semi-early cycle, R-resistant, MR-moderately resistant, MS-moderately susceptible, S-susceptible. 
HS Pereira et al.

\section{SEED PRODUCTION}

BRS Notável was registered in the National Register of Cultivars (RNC) of the Brazilian Ministry of Agriculture, Livestock and Supply (MAPA) on March 3, 2011 (no. 27.808) and the application for cultivar protection was submitted. Embrapa Technology Transfer will be in charge of the seed production.

\section{CONCLUSIONS}

The common bean cultivar BRS Notável has a mediumearly-maturing cycle, high yield potential, yield stability, light-colored grains with a similar size to cultivar Pérola, and high resistance to anthracnose, fusarium wilt, common bacterial blight and curtobacterium wilt.

BRS Notável is suitable for sowing in the following states and seasons: rainy, dry and winter in Goiás, Distrito Federal, Bahia and São Paulo; winter and dry in Mato Grosso; rainy and dry season in Espírito Santo, Paraná, Santa Catarina, and Rio Grande do Sul; winter and dry season in Tocantins and Rio de Janeiro; dry season in Mato Grosso do Sul; and rainy season in Maranhão, Pernambuco, Sergipe, Alagoas, Rio Grande do Norte, Ceará, Paraíba, and Piauí.

\section{REFERENCES}

Abreu AFB, Ramalho MAP, Carneiro JES, Gonçalves FMA, Santos JB, Del Peloso MJ, Faria LC, Carneiro GES and Pereira Filho IA (2004) BRSMG Talismã: common bean cultivar with Carioca grain type. Crop Breeding and Applied Biotechnology 4: 372-374.

Carbonell SAM, Chiorato AF, Ito MF, Perina EF, Gonçalves JGR, Souza OS, Gallo PB, Ticeli M, Colombo CA and Azevedo Filho JA (2008) IAC Alvorada and IAC Diplomata: new common bean cultivars. Crop Breeding and Applied Biotechnology 8: 163-166.

Del Peloso MJ and Melo LC (2005) Potencial de rendimento da cultura do feijoeiro comum. Embrapa Arroz e Feijão, Santo Antônio de Goiás, 131p.

Faria LC, Costa JGC, Rava CA, Del Peloso MJ, Melo LC, Carneiro GES, Soares DM, Díaz JLC, Abreu AFB, Faria JC, Sartorato A, Silva

\section{ACKNOWLEDGEMENTS}

The cultivar was assessed by the following partner institutions: Embrapa Arroz e Feijão; Embrapa Transferência de Tecnologia; Embrapa Tabuleiros Costeiros; Embrapa Agropecuária Oeste; Embrapa Semi-árido; Empresa de Pesquisa Agropecuária e Extensão Rural de Mato Grosso; Instituto Agronômico de Pernambucano; Fundação Estadual de Pesquisa Agropecuária do Rio Grande do Sul; Secretaria de Agricultura do Estado de Goiás; Instituto Agronômico de Campinas; Empresa de Pesquisa Agropecuária e Extensão Rural de Santa Catarina; Instituto Agronômico do Paraná; Universidade do Centro-Oeste; Fundação de Ensino Superior de Rio Verde; Embrapa Cerrados; Instituto Capixaba de Pesquisa, Assistência Técnica e Extensão Rural, Empresa de Pesquisa Agropecuária do Estado do Rio de Janeiro; Embrapa Milho e Sorgo; Universidade Federal de Lavras; Universidade Federal de Viçosa; Universidade Federal de Uberlândia; Empresa de Pesquisa Agropecuária de Minas Gerais; Embrapa Trigo; Universidade Federal de Santa Maria; Instituto Federal Goiano; Instituto Luterano de Ensino Superior/Universidade Luterana do Brasil; Embrapa Soja; Universidade Estadual Paulista; Universidade Federal do Mato Grosso do Sul; Universidade Estadual do Mato Grosso do Sul; Universidade Estadual de Goiás; and Universidade Federal do Tocantins.

HT, Bassinello PZ and Zimmermann FJP (2004) BRS Requinte: new common bean Carioca cultivar with delayed grain darkness. Crop Breeding and Applied Biotechnology 4: 366-368.

Faria LC, Del Peloso MJ, Melo LC, Costa JGC, Rava CA, Carneiro GES, Díaz JLC, Faria JC, Silva HT, Sartorato A, Bassinello PZ and Trovo JBF (2008) BRS Cometa: a carioca common bean cultivar with erect growth habit. Crop Breeding and Applied Biotechnology 8: 167-169.

Melo LC (2009) Procedimentos para condução de ensaios de valor de cultivo e uso em feijoeiro-comum. Embrapa Arroz e Feijão, Santo Antônio de Goiás, 104p. (Documentos, 239).

Melo LC, Del Peloso, MJ, Pereira HS, Faria LC, Costa JGC, Díaz JLC, Rava, CA, Wendland A and Abreu AFB (2010) BRS Estilo: common bean cultivar with Carioca grain, upright growth and high yield potential. Crop Breeding and Applied Biotechnology 10: 377-379. 